Tourism Research Journal

E-ISSN: 2598-9839

2019, Vol. 3 No. 2

\title{
The Role of Multimedia in Developing Ecotourism Branding of Yogyakarta Special Region (DIY)
}

\author{
Damiasih $^{1}$, Isdarmanto ${ }^{2}$ \\ Sekolah Tinggi Pariwisata Ambarrukmo Yogyakarta \\ 1Ami_pastel@gmail.com \\ spais.atonk@gmail.com
}

\begin{abstract}
In the current millennium and globalization era, the multimedia aspect has a very important role in the dissemination of all information and news through faster and more effective information technology. This is very important to learn, because every professional individual must be able to access all kinds of diverse programs in multimedia applications. This study uses qualitative research to understand the problems deeper. The purpose of this research is to find out the positive implications of multimedia in developing regional ecotourism, and to anticipate the negative implications of the multimedia in spreading false news. Spreading public lies can create serious problems for the community. This results in the emergence of contradictions, hostilities and legal problems that ads to crime. The role of multimedia is expected to be able to provide many benefits in the exchange of information, technology in aspects of life, culture, politics and social economy, especially for the development of ecotourism branding in the Special Region of Yogyakarta.
\end{abstract}

Keywords: Multimedia, Branding; Ecotourism Development 


\section{A. Introduction}

\section{Background}

The present development of tourism speeds up the growth of political, economic, social and cultural societies, as well as networks and infrastructure. Communicative multimedia networks allows the public to access such development and cyber communication accelerates information distribution. In this case any false information spread quickly, unclear and false information (hoax) or any information without accurate and real data will became problematic.

Advanced information technology adds on multi features in every gadget to facilitate communication and other functions. Smartphones are now parts of global people' lives, the increasing use of multimedia allows tourism activities to be easily, accessibly, and increasingly performed in community travel activities. As a result, tourist communities are able to critically select any kinds of tourism activities, and they can travel more frequently. In other hand, tourism business competition is more competitive, making each region to promote their regional development with superior and attractive branding to win the market.

This study explores the use of multimedia networks for the development of regional ecotourism marketing for more effective and efficient practices to increase the region's competitiveness. The research location is in Yogyakarta special region. The development of ecotourism through branding in major cities in Indonesia and abroad has shown significant results for economic growth, culture, and the social welfare. The Governments of Yogyakarta Special Region (DIY) of Sleman, Bantul, Kulon progo, Gunung Kidul regency and Yogyakarta municipalities have been able to enhance the changes and innovations to increase the attractiveness of ecotourism in their respective regions.

Each district creates tourist spots and creative event activities as a breakthrough in tourism development by using their own slogan shared in multimedia. The branding slogans from each regency such as: Sleman Sembada means (Healthy, elegant, Prosperous and Even, Clean and Cultured, Safe, Peaceful and Dynamic), Bantul Projotamansari means (Productive, Professional, Green area, Orderly, Safe, Healthy, Beautiful), Kulonprogo Binangun means (Clean, Beautiful, Priority, Safety, Reason, Team work, Reliable) Gunungkidul Handayani means (Green, Safe, Normative, Dynamic, Charitable, Confident, Nurturing, Value Added, Beautiful), Yogya Municipality of Mangayu Hayuning Bawono (Clean, Healthy, beautiful and comfortable).

This study focuses on the development of tourism business based on the development of advanced multimedia. It covers the aspect of strength and the link of the network, to quickly access all forms of information needed in branding of marketing program. The use of multimedia with branding is a form of concern for the value of creativity possessed by human resources as intellectual property. The use of professional human resource assets is an effort to create competitive advantages that other parties do not necessarily have. One 
of the strategic response to the aspects of public awareness as tourism actors must be able to move forward and be affiliated with the sophistication of today's multi-media network technology.

The role of multimedia itself is determined by the extent of the sophistication of human resources in accessing networks by utilizing the marketing of various company products, tourism objects, destinations and regional ecotourism through packaging of attractive, unique and beautiful branding designs, and giving all means in the marketing positioning aspect. In addition of the role multimedia has created branding access faster in responding to public trust and sales strategies in its marketing concepts. Thus existing human capital assets are the determinant key of success to create competitive advantages that others do not necessarily have. The aspect of human resources becomes increasingly important as a foundation in building tourism competitive advantage through multimedia if professionally empowered.

According to the World Tourism Organization (2004), the success of developing the tourism industry 4.0 is inseparable from the involvement of the Penta-Helix role such as ABCGM namely Academic, Business, Community, Government and Multi-media must be able to create people awareness in tourism. The role of regional tourism branding marketing through multimedia is able to encourage the growth of the number of tourist visits to recommend regional ecotourism destinations. Because with the sophistication access role of multimedia as soon as individuals and groups of communities could find out directly the interesting data of ecotourism offered.

Branding is the main base in building tourist trust, while the role of multimedia as an information medium to be able to convince buyers and closing the sales through the creation of attraction, trust, awareness and tourism positioning concepts. But mostly the local people were lack of the awareness. Meanwhile in the Developing countries has understand to the growth in other countries and create innovation through benchmarking from other countries that have succeeded in building branding image by their local people awareness. Thus the strategy for regional ecotourism development has required hard work of the people to build brand image, by creating attraction, developing tourism service products through improving public services by developing infrastructure, facilities and to preserve and maintain the development tourism in a sustainable manner.

Simon Anholt, Moilanen, \& Rainisto, (2009) states that the development of branding is an imaging strategy effort in all aspects of a destination through strategic innovation in managing infrastructure facilities and community empowerment from the economic, commercial, social, cultural and good governance aspects of the government. The development branding of a smart cities is through the city multimedia must have a characteristic that all information exposure can be identified functional and non-functional quality vastly. Furthermore, a city has good branding, if the city has a good reputation 
with different characteristics that can be easily identified, such as the appearance of the city, the experience of people in the city, public trust, and people who inhabit the city.

Yuli, (2011) says branding is a hot issue in almost every region in Indonesia. Through the role of multimedia several major cities such as Bandung under Mayor Ridwan Kamil has succeeded establishing several areas built to become a smart city in Indonesia. The City of Banyuwangi Regency under Azwar Annas has enhance Banyuwangi with Kali LO River to become famous, and Tuhad City of Badung in Denpasar Bali and others. In fact, reform era in Indonesia has changed the impact of freedom of opinion and innovation towards people's lives. However, public awareness in supporting tourism is still low. For example, a commitment with the Seven Attraction program "SaptaPesona" (Aman, Tertib, Bersih, Sejuk, Indah, Ramah Tamah dan Kenangan) that has been socialized by the government in every region, in fact the lack of sapta pesona is the awareness of some local people that has not being care or even has been forgotten off it. This problem must be taken seriously by all tourism stakeholders in each region.

The negative impact of the development of social media applications has often been misused with the emergence of news gimmicks, hoax, and the spread of viruses on IT networks such as: Runsomeware, Stuxnet, Drunkgirl, Win32 / Ramnit.F, Trojan, and Brontok. WanaCry Runsomeware locks all important documents. Drunk girls are malware that can post automatically, which is a trend a few years ago. Stuxnet can damage Scada or damage the hard disk and flash disk. Win32 / Ramnit.F is a Trojan virus that has the ability to clone so that the memory becomes full, which hides in the application office. The Brontok virus is able to overload the server, and the Didos virus can overload the main network of computer servers.

\section{Formulation of the problem}

Based on the background of the problems described above, mainly from a lack of public awareness, and the role of information by multimedia technology were very positive, cannot be optimized in developing regional ecotourism in DIY. With a variety of creative branding changes by updating interesting presentations but must also pay attention to the negative implications of accelerating multimedia information creating a negative image, because through DIY Tourism branding that is not in accordance with reality, on the contrary causes tourists to move to other areas.

An important phenomenon of tourism development in Yogyakarta makes the solution formulated as follows: a).Awareness of local people in managing Yogyakarta tourism assets related through city imaging in multimedia, b). The strategy of the regional government in handling city branding met with the target of developing Yogyakarta tourism with a multimedia role, c).Strategies to improve the development of sustainable Yogyakarta ecotourism through 
multimedia branding to overcome challenges in global tourism business competition.

Then problem research needs to be formulated with the following questions:

1. How to enhance the development of ecotourism in Yogyakarta Special Region by the role of multimedia access and be able to provide attractions for tourists to come to Yogyakarta?

2. How can the development strategy of tourist destinations from each district and Yogyakarta municipality be implemented in an integrated and synergize well?

3. What is the effort to empower the role of Penta Helix in the development and preservation of regional ecotourism in DIY

\section{Research Purpose}

To enhance the Indonesia's branding slogan "Wonderful Indonesia" was replaced with the slogan "Enchantment of Indonesia" (Pesona Indonesia) could make several changes in the world branding of Indonesia. Otherwise each province in Indonesia also has different sub-branding that has adjusted to the changed the slogan "Never Ending Asia", becoming a new branding slogan in 2017 "Jogja Istimewa" which has the distinctiveness of Yogyakarta as a special area with a myriad of uniqueness and unique culture that is expected to increase tourism growth in Yogyakarta. And one way to deal with branding competition in the Tourism Sector is to bring certain city brands in Yogyakarta.

Seeing in several ASEAN countries such as Singapore, Malaysia and Thailand, Philippines, Cambodia, Vietnam through branding they are able to absorb millions of tourists above the expected target. The marketing of tourism through multimedia is really growing rapidly in some countries with innovation and branding creation being the single determinant in the success of their tourism marketing. However, the reality of Indonesia's branding has not been able to meet the expected number of foreign tourists, which fully increases the need for participation of all Indonesian people.

\section{B. Literature Review}

\section{The potential of Ecotourism}

Indonesia as one of the countries that have a variety of biodiversity and supported by its stunning natural beauty, and has a diverse culture, has a great opportunity to rely on natural tourism (ecotourism) as a source of foreign exchange (Sulistio and Septiani, 2018). According to (Aditya, 2011) Indonesia suggests the high potency of ecotourism attractions, including the nature of ecosystems and its resources, nature biodiversity and traditional values spread in various regions of archipelagoes. However, the management of these ecotourism haven't been well prepared to enhance the attraction of tourist destinations in each region. Such as Yogyakarta as a Special Region is undeveloped in many tourism destinations. Its activities are really still limited to certain nature areas. 
Next Aditya state that Indonesia argues for high ecotourism tourism potential, including natural ecosystems and their resources, biodiversity and traditional values spread across various islands. However, managing ecotourism attractions is actually not yet developed in many tourist destinations. The activity is actually still limited to certain natural areas

Meijer, (2015) states the potential of ecotourism from various regions in Indonesia, this provides general information about existing economic and social developments. In an ecotourism perspective, environmental impacts from tourism activities and prevention of impacts and mitigation are discussed to support sustainable tourism goals and preservation of natural resource development programs. According to Meijer (2015) states that strategy in principle has related to the problem: Implementation policy, determination of objectives to be achieved, and determination of ways or methods of using infrastructure. Strategies are always related to three things, namely goals, facilities, and methods. Therefore, the strategy must also be supported by the ability to anticipate opportunities. Carry out its functions and roles in regional tourism development, the regional government must make various efforts in developing tourism facilities and infrastructure. Strategy is a term that is often identified with "tactics" which can be interpreted in a language as "concerning the movement of organisms in response to external stimulus". Meanwhile, conceptually the strategy can be understood as an outline of the direction in acting to achieve predetermined goals and under certain conditions in order to obtain the maximum expected results.

UNESCO, (2006) defined "Creative Tourism" as a tourism that is related to community development for a sustainable way of life. The activities provided to be harmonious and connected to history, culture, and the way of life in terms of learning and experience.

Boonpanya, (2006) the senior developer of the Assembly of Isaan Private Development Organizations, describes the history and evolution of local communities. The community has its own culture, is a miniature society with a production system, resource management, a health system, a knowledge and learning system, a judicial system, self-governance, and an economic system run by each family and the community. The goals of the community are that families can be self-sufficient and the community can survive.

Renata, (2016) states that the development of the regional tourism industry is thriving through branding on social media, with an emphasis on core propositions of regional product competencies (regional resources), which have a high impact on output, income, employment and technology, and bring development of a spillover area to the surrounding area. Meanwhile relate to social media (Dominggus. \& Oktavianus, 2007), states that in accordance with Tourism-based industries in line with the ideals of national industrialization to create prosperity for everyone, in a certain sense. Adequate and quality goods 
and services, people have purchasing power, because of decent income with high productivity, as well as evenly developing science and technology.

The implication of branding is that besides the aspect of industrial development, it also builds the resilience of the national economy, thus affecting the sovereignty of the nation. Furthermore, it was stated that the economy with an industry was able to absorb a lot of labor. The general objectives of industrial policies include: a) Providing employment for the population, especially from the growing agricultural sector, while employment opportunities are limited; b). To improve living standards, c). Improve balance of payments conditions; d). To improve the image and prestige of a nation so often there is a lighthouse project (economically it may not be profitable, but it can be a pride of a country).

\section{The role of human capital in social media}

Fukuyama, \& Francis, (2000) states that the main factor in encouraging economic growth is the growth of investment that can improve the quality of capital or human resources and physical conditions, to succeed in increasing the quantity of productive resources can increase the productivity of all sources through social network development, innovation and progress IT technology. Meanwhile, according to Cohen \& Prusak, (2001) the process of economic growth occurs when workers can reunite with capital. Solow-Swan focuses on how population growth, capital accumulation, technological progress and output interact in the process of economic growth. The company strives to get a good place in the position of competitive advantage by effectively utilizing various elements of its social capital

Cohen, Erik dan Scott A Cohen., (2012) states that the portfolio of social capital is built from social media (multi-media), trust, compliance with social norms and norms of reciprocity and various social cohesion and synergistic cooperation that is built will produce specific company resources, which have potential to improve the company's competitive advantage. A higher level is the uniqueness of the company beyond social capital as a higher competitive advantage.

Branding is a series of perceptions and imaginations that represent the Company's products and services. Many people refer to the brand as a logo, tag line or audio jingle, the brand is actually much bigger. So Brand is the essence or promise of what will be presented or felt. With important brands of product brands that allow buyers to easily identify products or services of a particular company. Brands are generally developed over time through: 1). Tags contain consistent messages. 2). Recommendations from friends, family members or coworkers. 3). Interaction with the company and its representatives. 4). Real experience using a product or service (generally considered the most important element in brand building). Those all has been well done from the existence of social capital factors. 
$\mathrm{Xu}$, Castro, Nurjanah, (2009) states that the development of tourism business through branding development innovation is more emphasized in the innovation process in organizations such as: social processes that produce innovation as creative individuals (context of individual creativity), organizational culture (organizational culture context), environment (environmental context), and socio-economic factors (socio-economic context). A successful tourism business must be managed through a marketing program through branding on well social media. The brand is no more than a name and logo. Brands are the basis on which companies build relationships with stakeholders. Brands are promising, propositions in mind, and promises made and must be fostered by social media.

Puspitawati, (2016) stated that to communicate brands to consumers, companies use internal and external communication, among others by promoting sales, events, public relations, direct marketing (sending catalogs, letters, telephone, fax or e-mail), sponsored products or service offerings that work with other companies as sponsors, and advertise ways to introduce products / services through all types of advertisements. (Khansari, Mostashari, \& Nasrin, 2014) state that perceptions of tourist destinations affect satisfaction and intention to visit related sites in the future, which of course depends on the ability of tourist destinations to provide unforgettable positive experiences gained during the tour.

Albert, (2015) stated that to introduce city branding to viewers of the city of Solo was very interested in making tourism products more attractive, one of which was by holding national and international cultural events. The event can act as a picture builder to attract people to the city. The event was also able to improve the profile of the city, so now the event is the main focus of the city. Big cities that are the main players in economic growth must have selling values that can be offered to a wide audience. One element of the success of a city can be seen from its success in providing a brand or brand that can distinguish it from other cities. In this case there is a need for marketing activities to convey information about the existence of the city and highlight special characteristics in the city. One way to deal with competition in the tourism sector is to bring city branding.

Simon Anholt, Moilanen, \& Rainisto, 2009) defines city branding as image management of a goal through strategic innovation and economic, commercial, social, cultural and government coordination. Moilanen, \& Rainisto, (2009) states that building a branding strategy involving urban communities in it cannot be an organizational task. All stakeholders must be involved in both the city government, business actors, media, local universities, cultural and heritage institutions, tourism actors, community leaders and others. The involvement of all stakeholders ensures a variety of perspectives and mapping of all city problems, making the implementation of the branding process a little lighter. City imagery demands a combination of philosophy and rigorous 
implementation, the top down approach applied in building a city image strategy will almost certainly fail. One of the most successful imaging campaigns in the world is New York City with the slogan "I Love NY" which was officially used since 1970. New York has always been a reflection of the belief that the strength of a city is its own city. We can see from what happened after the 9/11 terror, one of the factors in New York's recovery in a fairly fast time at that time was the success of rebuilding a sense of togetherness that has taken root in city life.

In the context of building city branding, the City of New York always involves its citizens to discuss and debate from the start to the point where the concept of city branding can be accepted by New Yorkers. Finally the city residents themselves were the advertisements walking and talking about promoting the city. Beyond reality, New York is indeed an attractive city in terms of culture, commercial climate, and other city entertainment.

The Indonesian state uses the slogan "Wonderful Indonesia" which was introduced in 2011, replacing the old "Visit Indonesia" slogan and still carries a colorful eagle logo. Wonderful Indonesia means: Extraordinary Nature, Extraordinary Culture, Extraordinary Humans, Extraordinary Food, Extraordinary value of Money. The form of the Garuda logo takes the concept of Garuda Pancasila as a symbol of the country. With the target number of tourists in 2015 cannot reach 10 million people on the target, but very only get 8.5 million. Compare with Phuket as part of a city that can get more than 13 million visitors.

Since 2016 this Indonesian slogan has been replaced with "Enchantment of Indonesia" which is expected to create a charm of natural beauty, culture and tourism products of the archipelago, in order to reach the target of 20 million by 2019. With this target, the Government needs very serious support from the entire community Indonesia in various tourist destinations to be able to develop their respective tourist destinations into tourist attractions throughout the world. With the potential of tourism destinations in Indonesia very specific and not owned by other countries, with integrated collaboration through branding on IT networks can certainly be achieved.

Recently in the UNWTO Tourism Video competition announced at the 22nd UNWTO General Session at the Intercontinental Century City Convention Center Hotel, Chengdu China (September 15) from 63 countries in the world, Indonesia won the overall champion with two categories of Indonesian "tourism" videos extraordinary: A beautiful world trip and the "People's Choice" category comes from e-voting from all world communities. By using the voice behind the song "Extraordinary World" by Louis Armstrong.

Brand definition is a name or term, design, symbol, or character that shows the identity or image of their product or service. The brand will show the image, name and quality of the product, the way the producer does business, and how to convince consumer producers. With branding allows people to identify product branding is a series of communication activities carried out by brand 
owners in the context of the process of building and improving the brand. Without good communication activities for well-organized and planned consumers, a brand is unknown and has no meaning for consumers or target consumers.

According to Chourabi, Abdelsalam, \& Reddick., (2012) states that major cities in a country have become more prominent main actors in regional and even global geographical relations, urban marketing efforts are a form of strength of competence with the relevance of city imaging or city imagery, which can help implement the development of marketing in developing cities. In the world of business, branding or brand is very important for the success of a company. Therefore, many companies allocating large budgets to be able to promote their brands to the public. In other words, brands can become Brand Equities. Therefore, the Indonesian tourism system needs to adopt the city branding concept that has been successfully developed in several countries.

Kesi, (2011) states that brands play an important role in promotional marketing with brand manufacturers that produce quality and reliable products. Branding is needed by manufacturers because manufacturers make the target consumers become familiar with the products offered, and to build trust for anyone who is the target of branding. A tourist does not trust someone who has just been seen, but with tourist branding becomes a faster belief. With increasing intensity because of frequent meetings, someone dares to be closer and wants to know each other, then branding can be said to be successful. But if the target consumer sees, reads or constantly listens to the same brand of products through multimedia, television, internet, magazines, billboards, newspapers, advertisements in books that face the target consumers do not take long to trust the product. Like the slogan "tick on shoes", people quickly recognized it as the Nike brand. Branding success can be a measure of the success of a product on the market. Current economic flows implicitly require branding activities to influence consumers if not worse.

(Robert Putnam, \& Khairuddin, 2000) states that social capital is human resources which can be seen as the most important investment to obtain new resources. As we know that something called a resource is something that can be used for consumption, stored and invested. The resources used for investment are called capital. Social capital is different from other popular terms of human resources. In human resources, everything refers to the energy dimension and individual expertise possessed by individuals. The idea of social capital is also very close to other social terminology because it is known as social virtue. The difference between the two lies in the network dimension. Social policy will be very strong and influential if it is associated with feelings of attachment to interact with the reciprocity in social relations.

(Hasbullah, \& Jousairi., 2006), states that the Implementation of the Concept of Social Capital Development: First, what social capital is basically capital that can be built with low investment, but requires investment to ensure 
its continued existence as an "isolation mechanism" "to provide opportunities for growth and the development of competitive advantage Second, developing social capital and socially historically embedded in more specific daily management mechanisms in the company, and therefore difficult to replicate and potentially lead to sustainable competitive advantage Third, relative social capital easy to reach, tax free, can be stored in the company, but the development is not easy because it requires an intense and continuous social touch, regarding it arises and lies in the national tourism development system that has not been maximized and has not been done holistically with the concept of development systematic. As a result, some of Indonesia's tourism sectors have not been well explored, even though the tourist attraction presents natural beauty and cultural uniqueness that can actually be sold to the fullest. Identification of the problem of developing the tourism sector in Indonesia related to marketing problems that have not been maximized so that there needs to be a significant increase.

So far some conclusions that written above can be drawn from the development of the application of the concept of social capital are: a) First, social capital is basically capital that can be built with low investment but requires sustainable investment to ensure its existence as an "isolation mechanism" to provide opportunities for growth and development of excellence competitive. b). Second, social capital is socially embedded historically in everyday management mechanisms so companies are firm and difficult to emulate potential advantages as sustainable competitive advantages. c). Third, social capital is relatively easy to reach, tax free, can be stored in the company, but is not easy to develop because it requires a strong and sustainable social touch.

\section{The role of social media in branding slogan}

The development of the world of tourism today emphasizes the slogan as a tourism potential marketing system that can grow the creative industry in it. Carrying the slogan "Never Ending Asia", Yogyakarta is able to become a growing tourism business. However, in 2017 the slogan was replaced with "Jogja Istimewa" which was expected to be able to compete with other major cities, because it was thicker with the assessment of Yogyakarta as a special area that had special treatment as a province such as DKI Jakarta as a Special Capital Region.

The Special Province of Yogyakarta in offering the concept of tourism according to its characteristics through the slogan of the success of city imaging has never been done in many other regions. (Aditya, 2011.).

(Allwinkle. \& Cruickshank P., 2011), states that branding requires technological development cannot be denied is one important determinant in the development of smart city concepts and more comprehensive for city branding, Nam and Pardo (2011) see that technology is not the only factor in the city 
smart, but there are 2). Other factors are institutional factors and human factors as supporters that grow and develop in the smart city branding concept.

The views of Nam and Prado are widely used by city governments, city managers, and parties involved in developing smart city concepts and applying them to branded cities in the world. Smart City Growth Factors Nam \& Pardo, (2011). According to Experts Urban areas that create sustainable economic development and high quality of life for citizens by increasing 6 points (governance, economy, quality of life, environment, human resources and transportation) that can be done with a strong information and communication technology infrastructure.

Chourabi et al., (2012) "City branding that monitors and integrates the conditions of all critical infrastructure, including roads, bridges, tunnels, trains, subways, airports, ports, communications, water, electricity, even large buildings, can optimize its resources with more good, plan preventive maintenance activities, and monitor security aspects while maximizing service to its citizens. "Harrison et al (2012) stated that the integration and monitoring of sustainable processes, optimizing natural resources, effective management, security aspects, and services maximized to the public must be prioritized in Smart Cities: linking the physical infrastructure of IT networks and business infrastructure to utilize intelligence city collective "Introduction to Urban Sustainability The main reason for smart cities is that having the right information at the right time, citizens, service providers, and cities can make better decisions that result in improved quality of life for urban sellers and the sustainability of the city as a whole.

Khansari et al., (2014) stated that there is an explicit need to understand the impact of smart cities on the environmental, social and economic sustainability of cities from a holistic perspective, the influence of smart city technology on the sustainability of cities branding.

\section{Research Methodology}

Kriyantono, Rachmat, Abdullah, \& Zulhamri, (2012) states with qualitative research, the first step is to carry out an inventory of research studies that can produce empirical data relevant to research. Determine the amount of relevant and quality data in accordance with the problems needed in this study. Identification is the most important and reliable problem that determines opportunities and challenges in empowering community innovation, and also implementing tourism development programs in the field. This research was conducted by combining several descriptive-evaluative approaches so that to obtain accurate and accountable information from interview data, a questionnaire was provided directly with potential informants. Interviews and questionnaires are grouped into several aspects: (social, environmental, institutional, government, marketing) and expectations. So get more basic data, based on the problem to be studied. Given in qualitative research, this research is about descriptive research, tends to use analysis. The process and meaning of 
perspective with the subject of research will be more highlighted in this qualitative research. A study of literature relevant to research can be used as a guide to focus on problems.

Qualitative research aims to explain phenomena in depth through deeper data collection. Qualitative research emphasizes the depth of data obtained by researchers. The deeper and detailed data obtained, the better the quality of this qualitative research. In contrast to quantitative, objects in qualitative research are generally limited in number. In this study, researchers participated in research activities to understand the conditions under study. Therefore, the results of this study require a depth of analysis from the researchers. In addition, the results of this study are subjective so that they cannot be generalized.

This research can be in accordance with the facts needed in the field. In addition, the bibliography can also be useful to provide an overview of the background of the research used by the researchers as a discussion of the results of the study. In this qualitative research, researchers depart from the selection of data that has propositions on research problems, utilizing relevant literature reviews and grounded research analysis as material that can provide the right explanation in research discussions, and finally be able to make new and more valuable studies. To deepen the quality and benefits of this qualitative research, researchers took several studies and opinions.

\section{The validity and reliability}

In the study of tourism development in certain areas of the Special Region of Yogyakarta, the development of their human resources is still far from the real application. Quality standards are expected, that awareness of tourism actors in the field is still not able to accommodate, provide product services to tourist satisfaction so their length of stay was still low, and makes turnover of tourist in small numbers, so the amount of tourist spending money in Yogyakarta has too small too.

Learning from other countries, in their tourism management, they are truly oriented towards brand imaging marketing that focuses on tourist satisfaction, by applying factor 4A mean (Accommodation; Attraction; Accessibility; Accessibility); should be added with awareness which is very important. So human resources are very competent in the product service awareness. And with a high awareness of loyalty in managing natural and artificial attractions can bring the number of foreign tourists, and too many of the few studies needed into the actual conditions by answering of the existing tourism business opportunities from any decision variables.

The role of local communities is as an intermediary variable that shows how the efforts of local communities can be activated and involved in developing a more competitive tourism business. Regarding the city branding program to the crucial problem becomes the selling point were the awareness of 
the public and the government to implement branding in the development of Yogyakarta tourism.

\section{Results \& Discussion}

Tourism development is largely determined by the role of tourism marketing. One factor in effective tourism marketing is using branding. Good branding is to choose the type of brand activity that is adjusted to achieving brand value in the value itself. Unknown brands must focus on building awareness. A brand that is well-known but poorly understood, that means working hard and explaining what brings consumers to the brand. Famous brands and understand, we must find activities that will increase interest to try or buy.

This activity is often referred to as brand activation. Furthermore, good brand branding is to choose the type of brand activity that is adjusted to achieving the value of the brand value itself. Unknown branding must focus on building awareness. Being a well-known brand that lacks understanding, it is necessary to work hard to explain what can give brands to consumers.

All winkle \& Cruickshank.,(2011) states that the development of branding as a positioning concept in marketing is also determined as a brand ambassador who is able to give trust to the target community. Tourism in Indonesia externally requires a "brand ambassador" that can be trusted by other countries as a tourism ambassador and President Joko Widodo traveled the world to represent Indonesia. While internally in tourist areas can use appropriate conditions for each region to be able to support the role of branding more effectively spread throughout the world.

Opportunities in regional tourism development are business opportunities where situations allow people to create new frameworks for creating and combining resources, when entrepreneurs feel confident about their benefits. The main difference between opportunities for branding on entrepreneurial aspects and other situations is that branding provides many business opportunities not only in non-profit thinking but also requires a new framework that optimizes existing branding of Jogja Istimewa as the branding of the smartest city in the world.

In accordance with the problem of developing the role of multimedia in branding in Yogyakarta, the main key is awareness and the role of the community as responsible human capital assets, sensitive and concerned about the environment, actively participating in managing and preserving ecotourism.

This study aims to identify how much the level of public awareness through the system of empowering social capital in maintaining and managing the tourism assets by new slogan branding "Jogja Istimewa". Effective socialization and empowerment programs from local communities must be fully aware and participate seriously in supporting the application of new city brands, as well as for the development of sustainable tourism. Maintain consistent harmonious 
relations between local communities, local governments and the role of the private sector in supporting the creation of Yogyakarta's new Tourism Branding to be more productive and competitive in the global tourism business competition. By answering the problem questions from the research described above, which is expected with the branding slogan "Jogja Istimewa" all local communities must be smarter, create innovation and creativity in creating a model of Yogyakarta's tourism development. Communities and local governments will pay more attention to the level of tourist needs and be ready to actively participate in business management as responsible tourism actors. Multiple effects factors can create a sense of awareness and loyalty towards tourism awareness, and make tourism an ever-growing industry, so that people are more fully responsible for operational activities and Yogyakarta tourism development targets. Thus, sustainable tourism in Yogyakarta can be developed to compete more competitively because the effective role of private shareholders, the government and the local community is able to distribute tourism imagery of the city's imagery of "Jogja Istimewa".

Wibowo., (2007), states that in branding there are three of the most important elements such as 3C: Clarity, Consistency, and Firmness (Constant always where needed) branding. First, because of pressure from incompetent competitors. Second, the pressure of changes in consumer behavior, which may be a result of technological change. Other reasons are the company's priorities have changed. The development of social tourism needs to pay attention to business opportunities and the increasing global tourism gap. The number of business opportunities for local tourism development but have not been caught and handled by tourism managers. Efforts to develop business strategies can be developed taking into account the business opportunities that have been made by several researchers and the phenomenon of tourism development and the increasing number of domestic tourists in Yogyakarta that are increasing every year. And create economic growth or a rapidly expanding business opportunity. For example, the increasing number of hotels, restaurants, catering businesses, transportation businesses, souvenirs \& crafts, peddlers and entertainment businesses, together with the development of MICE businesses through events, seminars, workshops, meetings, events and events, this has the potential for someone to open many kings business, especially restaurant business; catering or snacks from Yogyakarta or traditional food, which can be sold to tourists. The development of tourism potential in Indonesia must be carried out effectively through the "City Branding" strategy. One of them is done through efforts to improve the connectivity of tourist destinations in Indonesia.

The multimedia role of IT networks is very important in supporting city branding in marketing development strategies. It can create public trust and positioning concepts with confidence in the products offered. While tourism branding is determined by real conditions (1). The attraction of existing tourist attractions, (2). Accessibility makes it easy to reach locations smoothly, (3). These 
facilities require tourists and (4). The peculiar aspects of society in providing products and services enjoyed by tourists during their visit. The implication in the development of city branding is that it can create changes in attitudes towards people's behavior so that they can realize the importance of maintaining tourism assets from areas that must be maintained and developed as tourism objects. The awareness and involvement of the community to provide support for the city branding program is the strength of the application of the branding program that can run well, focusing on the goals for the sustainability of sustainable regional tourism.

\section{Scope of situation}

In the development of tourism products and services must also be met with quality standards with guaranteed quality, to respond to the main needs of tourists. The community of tourism actors must better understand and anticipate all, every need for all tourists, through conscious tourism, must pay attention to the ability to accommodate and anticipate awareness of managing all of Yogyakarta's tourism assets.

According to Simon Anholt et al.,(2009) defines the image of cities as management of objectives through strategic innovation and implementing coordination of economic, commercial, social, cultural and government regulations. City Branding is not just a slogan, but must be equipped with a more professional tourism management, and requires real socialization from all the people of Yogyakarta.

Local tourism actors must actively participate in supporting Yogyakarta tourism branding. To manage Yogyakarta tourist destinations not only from three aspects (Attraction, Accommodation and Accessibility) that are usually managed. But one more aspect of "A" must be added, namely awareness. Social awareness of tourism products and services must be considered in implementing tourism development in Yogyakarta. This is very important in managing the role of Yogyakarta Tourism that has not been fully implemented. This proves Yogyakarta as the second tourist destination after Bali Indonesia. But now it has dropped to sixth place, after Bali; DKI Jakarta; Lombok; Raja-Ampat; and Bandung, West Java. Awareness aspects that have been proclaimed and developed in other Asean countries and their commitments have been implemented in their tourism development programs.

The development of tourism in Indonesia and other countries were very significant growth, so that it can improve the economic life and social welfare of a country. Each region of the State seeks to make strategic efforts to foster and realize sustainable Tourism Development. Marketing factors play an important role in the development of tourism, through the development of information technology (IT) and the role of social media, capable of providing rapid 
information and acceleration processes. This is like tourism goods and services products which are also one of the activities of tourism products sold to countries in the world.

Suhono \& Ety Purwanti, (2016).Several regions in Southeast Asian countries are now aggressively increasing branding in tourism potential in their country to attract tourists from all over the world. Marketing with the concept of branding is one of the important factors for the success of government programs to support the development of their country's tourism. Branding is a strategic way to support more effective tourism marketing, which is carried out in the form of slogans and logos which at any time can be known and read through running text on various social media. Branding is a strategy carried out by the state or region to create a strong positioning in the target market, so that the country or region can be widely known throughout the world

Dongo, Kouassi., (2010) states that tourism is the spearhead of an area, to attract investors to the area. "In building an area, to attract investors, it is necessary to build tourism potential first, rather than offering new concepts to new investors to build industrial estates. Meanwhile Mbaiwa, \& AL Stronza., (2003) states that activities through various events through social media, both on a local, regional, national and international scale is one of the main forms of communication in city branding activities

Rahajeng, Ekowati, Sulistyowati. Tuminah, (2008) has mentioned that the city brand of Surakarta is "Solo the Spirit of Java". Branding with specific slogans is to communicate the benefits of the city of Solo, which is distinguished from other cities by showing the identity of the city of Solo as a cultural city. The slogan is inherent as the identity of the Solo region, and becomes a trademark for every promotion and effort to elevate superior products through multimedia effectiveness to the international region. Some developed countries facilitate large funds that will be allocated for brand marketing, so that it will change the image and brand packaging strategy as a form of creative ideas to develop regional marketing products. That are tailored to the development and changes in situational conditions of the region.

In January 2012, tourism and Southeast Asian slogans changed to feel warmth. A new branding was launched in the implementation of the Association of Southeast Asian Nations Tourism Forum in Manado, Indonesia. The event also agreed to establish a Tourism Market Research Group to analyze marketing trends, the situation and future of the Southeast Asian Tourism Association. The role of multimedia such as the example in the State of Brunei Darussalam claims to be the best country that preserves their forests on Kalimantan Island with the slogan "The Green Heart of Borneo"

By multimedia Cambodia force with the slogan of "Cambodia, Kingdom of Miracles" that Angkor Watt became a famous logo in world tourism because Angkor Watt is an attraction that has visited by a number of tourists in 2015 of around 3-4 million people Laos Slogan Country by "Simply Beautiful", with Dok 
Champa as a flower logo, known as Cambodia. This flower is Lao national flower which is often used to welcome guests who come or as decorations at parties. Lao people, Doc Champa means happiness in life and sincerity (joy in life and sincerity). And the shadow of Watt (Temgaiple Buddhists) on the flower symbol of Lao religious performances and attractions.

Malaysia with the slogan of: "Malaysia Truly Asia" is one of the most successful Tourism brands in Asia. Tourism has become one of Malaysia's main foreign exchange sources. Undeniably, with strong marketing throughout the world, Malaysia is able to wipe out 24 million foreign tourists and become the highest in Southeast Asia.

Myanmar's State Tourism Slogan is "Mystical Myanmar" This slogan is promoted because Myanmar is the most mysterious tourist destination and has not been widely explored throughout the world.

The Philippines with the slogan of "It's More Fun in the Philippines" is the new tour slogan that will be promoted from 2012 to now, the number of foreign tourist visits in 2015 will be 5 million years to be replaced. Filipino WOW slogan that has been used since 2002. With fresher slogans and logos.

The Singapore state with the slogan "Your Singapore" was launched in 2010 to replace the old "Uniquely Singapore" brand. Tourists in 2015 can bring in 15 million. This slogan is the fruit of research between the Singapore Tourism Board and related institutions. The new logo of Singapore tourism itself shows the shape of Singapore with attractive colors.

Thailand with the slogan "Amazing Thailand" is one of the most successful tours in the world, the slogan in 2015 can absorb 29.8 million tourists. Thailand has been using this slogan since 1997 and then followed by other countries in Southeast Asia. Thanks to its consistency in the tourism market, Thailand has become one of the leading tourist destinations in Southeast Asia. The sub slogan "Always amazes you" is the main reinforcement slogan and began to be used since 2010. In 2009, Thailand's sub slogan was "Extraordinary Value." So that it can boost the number of tourists more.

The Vietnamese nation has 6.5 million foreign tourists with the slogan "Eternal Enchantment of Vietnam" is Vietnam's new slogan that replaces their old slogan, "Hidden Enchantment of Vietnam". This slogan is used for tourism promotion 2012-2015. In 2011, around 6 million foreign tourists visited Vietnam and the marketing targeted in 2012 was able to attract attention.

The development of a successful information system has become one of the organizational performance indicators in the spotlight, not only from the operational aspects of the company, but also its relationship with customer trust. Organizations / companies with good Information Technology support will have added value from competitors in the form of a faster response, efficiency and effectiveness of performance improvement, identification and handling of problems more accurately, and trust in the delivery of work. This advantage 
makes many parties increase concentration in the development of information systems.

On the other hand, the information system development process is sometimes temporary and creates many problems such as lack of reliable human resources, the amount of investment costs for training and development, inadequate hardware support for classic problems, lack of management time to pay attention to system development detailed information. In order for information systems to function properly, we must actively manage, adapt technology to the situation and accept responsibility for success and failure problems more accurately, and trust in the delivery of work.

This advantage makes many parties increase concentration in the development of information systems. On the other hand, the information system development process is sometimes temporary and creates many problems such as lack of reliable human resources, the amount of investment costs for training and development, inadequate hardware support for classic problems, lack of management time to pay attention to system development detailed information.

According Suhono \& Ety Purwanti, (2016) the development of multimedia data collected can be in the form of text, images, audio, or video or a combination of data known as multimedia data. Which can be classified as: a). Input is an activity that includes the capture and arrangement of elements to be included in the system and processed.

b). Process is an activity that includes a transformation process that converts input into output. Whereas c). Output is an activity that includes sending elements produced by the transformation process to the final destination. d). Store Data is data that will be processed stored in a database or database because it can be used for the purpose of providing further information. Data in the database needs to be well regulated so that it produces good information and is also useful for efficient storage capacity. e). Data base is accessed or manipulated using software called DBMS (Database Management System). f). The Control System with continuous control of a system needs to be implemented and monitored to ensure the system runs normally and well so that if a bug or error occurs, it can be corrected so that operational activities run smoothly.

Furthermore, in the development of management information systems carried out through several stages, where each step produces more detailed results from the previous stage. The initial stage of information system development generally begins by describing the needs of users of the macro strategy approach system, followed by translations of strategic and medium and long-term organizational needs, usually for periods of 3 to 5 years.

The phenomenon of tourists visiting the country is abundant every tourist destination cannot be anticipated by tourism managers. And they produce attractions such as: dirty, worn, damaged infrastructure, traffic jams. To show the actors certain elements such as: hugs, violence, intimidation of tourists that damage the image of tourism, and make tourists dissatisfied. It must be 
recognized that the rapid development of tourism development has positive and negative impacts such as increased income, job creation and increased welfare. But also traffic congestion, environmental degradation and land conversion, especially agricultural land which is used as the development of tourist facilities such as hotel restaurants and other tourist attractions. This is the main problem in this research namely Tourism Awareness or Public Awareness.

This research study believes that the key to tourism development is a sensitivity factor in awareness, tourism can understand and respond quickly to all tourist needs. But awareness from all stakeholders is very important in managing tourism. In spite of that excessive use of multimedia also has a negative impact, because excessive freedom is often uncontrollable and does not pay attention to social ethics, defamation, harassment, coercion, which hurts others. Efforts to create competitive advantage through trust, with all efforts that are more effective when using human resource assets, are able to provide the best service to the tourism community. Some research in tourism development on the role of social capital is built through collaborative awareness applications from effective multimedia networking communities.

\section{E. Conclusions and Suggestions \\ Conclusions}

The findings of this study indicate that Yogyakarta city branding has a significant influence on image, and branding has a significant influence on purchasing decisions and the influence of urban image but is not significant for purchasing decisions. Thus, with the excellence of Yogyakarta branding is further to increase the promotion of Yogyakarta tourism throughout the world, especially in the new slogan branding "Jogja Istimewa". So that it will become famous among local people and other neighbors.

In carrying out the tourism development hypothesis through multimedia and branding, the city initially conducted a study of the real conditions of branding socialization in society, as the main determinant must be done in depth to provide concrete and accurate data information about all potential conditions of asset areas, weaknesses deficiencies main variable. The role of multimedia is very effective can be used as a supporting variable (variable determinant) that provides benefits in achieving the goal of developing more advanced and sustainable regional tourism as the dependent variable that can ensure the creation of community welfare and tourism business can increase economic competitiveness as a smart city of Jogjakarta

The role of multimedia networks by supporting the branding strategy, what we have learned in this study is about the development of tourism in the special region of Yogyakarta through the potential in marketing as a positioning of the tourism industry in Yogyakarta. IT networks with multimedia strengthen city branding need to get positive support, especially in the application of all tourism assets as a determined branding concept in Yogyakarta. The benefit of 
tourism branding will increase the number of tourists who come to Yogyakarta, which have been facilitated by innovation of a clean environment, beautiful city design, and comfortable city facilities arrangement, if the opposite occurs the complexity and congestion of the city will be the main problem in Yogyakarta today, what for in the future? Recommendations for developing the image of the city Yogyakarta tourism stakeholders and the government must improve quickly with innovation and commitment of developing infrastructure creativity to facilitate all tourists who visit to Yogyakarta.

\section{Suggestions}

Need to maintain regional tourism assets and provide excellent services for foreign tourists to create customer satisfaction. Regarding the new brand "Jogja Istimewa", people must truly understand the meaning of the slogan itself. Paying attention to the capacity of tourists as one of the disciplines of tourism services, but must be applied and rely on tourism branding. The image of the city of tourism is more useful for Tourism Resources and must be taken seriously by the local community. Because the sound of professional tourism agents, who have the awareness, loyalty and responsibility able to maintain their own tourism asset of Yogyakarta.

Need optimization of forum group discussion (FGD) and create joint commitment to anticipate the challenges of global competition requires the concern of local communities as tourism assets, and must be empowered to promote the development of sustainable tourism in the special region of Yogyakarta. Yogyakarta tourism stakeholders must support and apply the branding concept to critical thinking, create creative and innovative ideas to solve internal problems that have been carved by the new brand "Jogja Istimewa". Important issues are made from the lives of travelers and the mindset of individuals or groups of people that can vary and change every day.

Awareness is the selling point of branding and to gain trust from customers. So the awareness of local community needs to be adapted to the brand "Jogja Istimewa". And maintain local wisdom to build a positive mental attitude from the local community that is not so easy but it is very important, enthusiasm and intention to participate in socialization branding to change their lives better. The role of local communities requires the approval of other parties related to regulations and a commitment to realize the high awareness set out in government policies and regulations, by increasing the attitudes and behavior of local people in the concept of branding the city of Yogyakarta. 


\section{REFERENCES}

Aditya, Yuli. (2011). City branding sebagai strategi pengembangan pariwisata ditinjau dari aspek hukum merek. Jurnal Ilmiah Ilmu Hukum QISTI, 5, 2011.

Albert. (2015). Governing the smart city: International Review of administrative science.

Allwinkle S., \& Cruickshank P. (2011). Creating Smarter Cities. Physical Journal Special Topics, 214: 481-518 .

Boonpanya. (2006). Realitas subjektif, memberikan tekanan terbuka tentang kehidupan social, khususnya tentang perilaku pedagang. Jurnal Ilmiah Ekonomi Bisnis, 19,.

Chourabi, Abdelsalam, \& Reddick. (2012). Understanding Smart Cities. Fakultas Geografi UGM.Yogyakarta.

Cohen, Erik dan Scott A Cohen. (2012). Authentication: Hot And Cool. Annals of Tourism Research., 39 (3): 1295-1314.

Cohen, \& prusak. (2001). Social Capital. Jakarta: PT Gramedia Pustaka Utama.

Dominggus., \& Oktavianus,. (2007). Tahap awal dari industri padat karya yang berdasarkan Industrialisasi. Sydney: Allen \& Unwin..

Dongo, Kouassi. (2010). Analysing Environmental Risks and Perceptions of Risks to Assess Health and Well-being in Poor Areas of Abidjan . International Journal of Civil and Environmental Engineering.

Fukuyama, \& Francis,. (2000). Social Capital dalam Harrison, Lawrence E dan Samuel P Huntington, Culture Matters, How Values Shape Human Progress. Basic Books.

Hasbullah, \& Jousairi. (2006). Social Capital Menuju Keunggulan Budaya Manusia Indonesia). Jakarta: MR-United Press.

Kesi, wijayanti. (2011). Model pemberdayaan masyarakat. Jurnal Ekonomi Pembangunan, 12, 15-27.

Khansari, Mostashari, A, \& Nasrin. (2014). Impacting Sustainable Behavior and Planning in Smart City. International Journal of Sustainable Land Use and Urban Planning.

Kriyantono, Rachmat, Abdullah, \& Zulhamri. (2012). Perception of Public Relations. Jakarta: Erlangga.

Mbaiwa, \& AL Stronza. (2003). The effects of tourism development on rural livelihoods in the Okavango Delta, Botswana. Journal of Sustainable Tourism.

Meijer, A. (2015). Governing the smart city: a review of the literature on smart urban governance. International Review of Administrative Science.

Nam, T., \& Pardo, T. A. (2011). Conceptualizing Smart City with Dimensions of Technology, People, and Institutions. Center for Technology in Government University at Albany, State University of New York, U.S. 
Puspitawati, Ika Warakasih. (2016, 12). smart city peluang dan tantangan untuk yogyakarta berbudaya. Berita Bappeda DIY.

Rahajeng, Ekowati dan Sulistyowati Tuminah,. (2008). Prevalensi Buku Saku

Dasar Patologis penyakit robbins.

Http://Repository.Usu.Ac.Id/Bitstream/123456789/6673/1/08E00743.Pdf. 33.

Renata, P. D. (2016). Governing Smart Cities. Social Science Computer Review.

Robert D Putnam, \& Khairuddin. (2000). Pembangunan Masyarakat. Yogyakarta: Liberty.

Simon Anholt, Moilanen, \& Rainisto. (2009). City Branding sebagai manajemen citra suatu destinasi melalui inovasi strategis. Https://Ejournal.Unsrat.Ac.Id/Index.Php, 7.

Suhono, \& Ety Purwanti,. (2016). Perancangan Model Pengawasan sebagai Bagian dari Tata Kelola Implementasi Smart City Menggunakan COBIT 5 (Studi Kasus Kota Bandung). National Proceeding E-Indonesia Initiatives (EII) Forum Ke XIII 2016, 20-21 Juli 2016, Surabaya.

Sulistio, T., \& Septiani, T. (2018). The Influence of Accessibility And Facilities on Visitor Satisfaction in Mangrove Forests Pantai Indah Kapuk. TRJ Tourism Research Journal, 2(1), 50-57. doi:10.30647/trj.v2i1.28

UNESCO. 2006. (n.d.). Towards Sustainable Strategies for Creative Tourism. Discussion Report of the Planning Meeting for 2008. International Conference on Creative Tourism, Santa Fe, New Mexico, U.S.A., October 25-27, 2006. 13.

Wibowo. (2007). Manajemen Kinerja. Jakarta.: PT. Raja GrafindoParsada:

Xu, Castro . S Nurjanah. (2009). Peran manajemen inovasi.

Yuli, A. (2011). City branding sebagai strategi pengembangan pariwisata ditinjau dari aspek hukum merek. Jurnal Ilmiah Ilmu Hukum QISTI Vol. 5 No., 5(1). 